\title{
Family health strategy and equity in prenatal care: a population based cross- sectional study in Minas Gerais, Brazil
}

Mônica Viegas Andrade ${ }^{1,3^{*}}$, Kenya Valéria Micaela de Souza Noronha', Allan Claudius Queiroz Barbosa², Michelle Nepomuceno Souza', Júlia Almeida Calazans' ${ }^{1}$, Lucas Resende de Carvalho', Thiago Augusto Hernandes Rocha ${ }^{2}$ and Núbia Cristina Silva ${ }^{2}$

\begin{abstract}
Background: Prenatal care coverage is still not universal or adequately provided in many low and middle income countries. One of the main barriers regards the presence of socioeconomic inequalities in prenatal care utilization. In Brazil, prenatal care is supplied for the entire population at the community level as part of the Family Health Strategy (FHS), which is the main source of primary care provided by the public health system. Brazil has some of the greatest income inequalities in the world, and little research has been conducted to investigate prenatal care utilization of FHS across socioeconomic groups. This paper addresses this gap investigating the socioeconomic and regional differences in the utilization of prenatal care supplied by the FHS in the state of Minas Gerais, Brazil.
\end{abstract}

Methods: Data comes from a probabilistic household survey carried out in 2012 representative of the population living in urban areas in the state of Minas Gerais. The sample size comprises 1,420 women aged between 13 and 45 years old who had completed a pregnancy with a live born in the last five years prior to the survey. The outcome variables are received prenatal care, number of antenatal visits, late prenatal care, antenatal tests, tetanus immunization and low birthweight. A descriptive analysis and logistic models were estimated for the outcome variables.

Results: The coverage of prenatal care is almost universal in catchment urban areas of FHT of Minas Gerais state including both antenatal visits and diagnostic procedures. Due to this high level of coverage, socioeconomic inequalities were not observed. FHS supplied care for around $80 \%$ of the women without private insurance and $90 \%$ for women belonging to lower socioeconomic classes. Women belonging to lower socioeconomic classes were at least five times more likely to receive antenatal visits and any of the antenatal tests by the FHS compared to those belonging to the highest classes. Moreover, FHS was effective in reducing low birthweight. Women who had prenatal care through FHS were $40 \%$ less likely to have a child with low birthweight.

Conclusion: This paper presents strong evidence that FHS promotes equity in antenatal care in Minas Gerais, Brazil. Keywords: Antenatal care, Prenatal care, Primary health care, Family health strategy, Health equity, Brazil

\footnotetext{
* Correspondence: mviegas123@gmail.com

${ }^{1}$ CEDEPLAR, Federal University of Minas Gerais - UFMG, Av. Antônio Carlos 6627, sala 3006, Belo Horizonte, MG 31270-901, Brazil

${ }^{3}$ Department of Global Health and Population, Harvard T.H. Chan School of Public Health, Boston, MA, USA

Full list of author information is available at the end of the article
}

\section{Ciömed Central}

(c) The Author(s). 2017 Open Access This article is distributed under the terms of the Creative Commons Attribution 4.0 International License (http://creativecommons.org/licenses/by/4.0/), which permits unrestricted use, distribution, and reproduction in any medium, provided you give appropriate credit to the original author(s) and the source, provide a link to the Creative Commons license, and indicate if changes were made. The Creative Commons Public Domain Dedication waiver (http://creativecommons.org/publicdomain/zero/1.0/) applies to the data made available in this article, unless otherwise stated. 


\section{Background}

Prenatal care encompasses a wide spectrum of clinical procedures and assistance for pregnant women to improve maternal and child health. Not only are the benefits of prenatal care widely recognized in the literature - - but in low and middle income countries, appropriate prenatal interventions are cost-effective [1-7]. Notwithstanding all the evidence of the benefits of prenatal care, (including reduction of neonatal tetanus, reduction of low birthweight and preterm-delivery, and screening and treatment of infectious diseases), its coverage is still not universal or adequately provided in many low and middle income countries [2, 8-13]. Limited prenatal coverage remains one of the main barriers that signifies the presence of socioeconomic inequalities in prenatal care utilization. Socioeconomic (education, income and gender) inequalities matter for access to prenatal care. For instance less educated and lower income women have less information and resources to seek care. Besides, they usually have less confidence in healthcare providers and lower autonomy in households and live in rural/remote areas. In these areas, access to healthcare and transportation facilities is limited since they are in lower supply [9, 14-23].

In Brazil, prenatal care is supplied for the entire population at the community level as part of the Family Health Strategy (FHS), which is the main source of Primary Health Care (PHC) provided by the public health system. FHS has played an important role in the prevention of diseases and the promotion of health awareness since it constantly monitors families through systematic household visits by Family Health Teams (FHT). According to this strategy, families are the focus of public health policies that cover primary care for all population groups, from the newborn to the elderly individuals, irrespective of their health conditions. Family Health Teams (FHT) are mainly composed of family physician, nurse, nursing assistant and at least 4-12 community health agents (CHA) and are based in Health Units. Each FHT is responsible for at most 3,450 peopled living a catchment area [24]. The FHT must be able to detect symptoms of disease and to refer individuals to the needed healthcare unit. In addition, health promotion and disease prevention activities such as encouraging child immunization, antenatal care, and special care to individuals who suffer from diabetes, hypertension or coronary diseases are stimulated. Personal and household hygiene advices are also provided by the CHA in order to prevent and control infectious diseases, especially those caused by vector-borne viruses and bacteria $[24,25]$. CHA play a fundamental role as they act as a bridge between the population and Health Units. They are responsible for families' enrolling and are required to visit each household on a monthly basis in order to identify risk factors and vulnerable conditions. Besides, $\mathrm{CHA}$ are required to promote active search of pregnant woman and refer them to receive prenatal care. This protocol contributes to strengthen the bond between health professionals and pregnant women.

Some empirical evidence has already been raised about the importance of FHS showing a robust impact on reducing infant mortality [26-28] and decreasing hospitalizations due to conditions sensitive to primary care [29-31]. Related to antenatal care FHS has contributed to scale up the coverage and to promote an equal access to adequate care $[32,33]$. However, Brazil has some of the greatest income inequalities in the world [34]. Additionally little research has been conducted to investigate prenatal care provided by FHS across socioeconomic groups.

This paper addresses this gap by investigating the disparities in the utilization of prenatal care supplied by the FHS in the state of Minas Gerais, Brazil, using data from a population-based study conducted through a household survey. Minas Gerais is the third largest economy in Brazil and has strong socioeconomic disparities. Hence, its regional heterogeneity largely reflects that found in Brazil, making it representative of the country's socioeconomic and epidemiological profiles [35].

\section{Methods}

This study is classified as cross sectional-ecological based on primary databases. Data were obtained from a household survey undertaken in Minas Gerais in 2012. This survey investigated healthcare services provided by the Family Health Strategy (FHS). A probabilistic multistage sample stratified by the thirteen health macro regions was defined in order to be representative of the population living in urban areas in the state of Minas Gerais [36]. The primary and secondary units sampling were respectively FHT and households. The definition of the number of FHT and households surveyed was based on the total of FHT in Minas Gerais in 2011 considering a margin of error of 5\%. Therefore, 208 FHT were investigated in the State and equally distributed among the 13 health macro regions. The selection of municipalities took into account the socioeconomic disparities observed in the state measured by the Municipal Human Development Index (MHDI) and the number of FHT [35]. A total of 173 municipalities were selected and distributed in order to guarantee that 16 FHT were investigated in each health macro region. After the selection of municipalities, households were randomly drawn in geographical catchment areas of each health units. Since not all Health Units had available a map of catchment areas, we used the Official Register of Addresses provided by the Brazilian Institute of Geography and Statistics to identify the households (Fig. 1) located in 


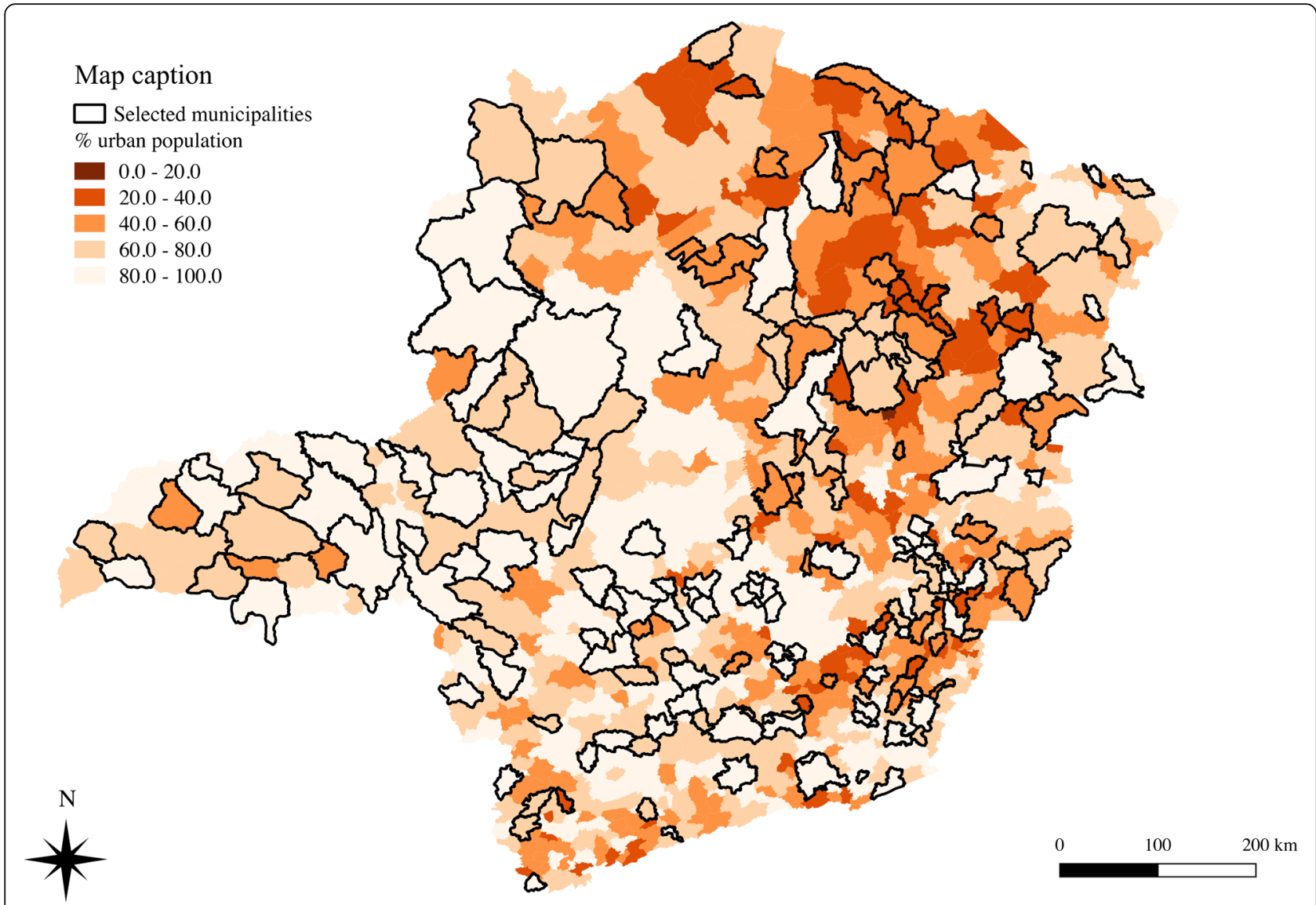

Fig. 1 Percentage of population living in urban areas in each Municipality of Minas Gerais state and selected municipalities investigated in the survey

the geographical area of each health unit, named here as potential catchment areas [37]. To estimate the number of households located in these potential catchment areas, the Health Units were georeferenced using the software ArcGIS and two assumptions were made: 1) each FHT provides PHC on average for 3,450 individuals; and 2) it was considered an average of four persons per household. In that manner, each potential catchment area would include 850 households.

The sample size comprises 1,420 women aged between 13 and 45 years old who had completed a pregnancy term with a live birth in the last five years prior to the survey. These women were selected if their child under five years old were living with their mothers in the same household. Mothers whose children did not survived were not included in the sample. As a result, maternal or infant mortality were not possible to be analyzed. In the case of more than one pregnancy during the five-year-period, only the pregnancy of the youngest surviving child was investigated. This study was approved by the institutional review board of the Federal University of Minas Gerais, protocol \# 04200203000-10.

\section{Variables}

The outcome variables for the study were received prenatal care, number of antenatal visits, late prenatal care, antenatal tests and tetanus immunization. Antenatal visits were categorized into less than 6 and 6 or more visits as recommended by the Brazilian Ministry of Health [38, 39]. Late prenatal care was defined as having received the first antenatal visit after three months of pregnancy. The antennal tests included blood, urine, Sexually Transmitted Disease (STD) and toxoplasmosis test. As the tetanus immunization ensures protection during a ten-year period, some women do not take the vaccine during pregnancy since they have already been immunized before. Failure to consider this information may underestimate immunization coverage against tetanus. In this study, the coverage of tetanus vaccine immunization was estimated combining the information regarding immunized mothers during pregnancy with those who were already immunized.

Besides antenatal care components, we also investigated low birthweight using World Health Organization definition: infants born weighting less than 2,500 grams regardless of gestational age [40]. Since the Brazilian 
Health System is mixed, we also investigated the types of providers that supplied antenatal care that allowed for the role of FHS to be distinguished from that of the other antenatal care providers. Three types of providers were considered: FHS, other public health care facilities and private care (out-of-pocket and health insurance).

The independent variables for the study comprise the socio-demographic characteristics of the pregnant women such as mother's age during pregnancy, socioeconomic class, mother's level of education, region of residence, private health insurance coverage and diagnosis of hypertension and diabetes at the moment of the interview. Educational level was defined by an indicator with four categories representing the completed education level achieved by the respondents that were interviewed: 1) less than completed middle school; 2) completed middle school and incomplete high school; 3) completed high school; 4) over high school. Socioeconomic class is a categorical variable defined by the Brazilian Association of Research Companies [41]. This criterion classifies the population according to possession of household goods, number of domestic employees, and the highest educational level in the household. A wealth index was built for each household that was classified into three socioeconomic classes: A/B, C, and D/E. A descriptive analysis and multivariate logistic models were generated based on the outcome variables.

\section{Results}

Table 1 presents the distribution of characteristics of the women that were interviewed. The majority of them belonged to the middle class and had at least completed middle school. Around $25 \%$ were covered by private health insurance reflecting the same distribution observed for Brazil [42]. Regarding age, 14\% was classified as risky pregnancy since $11 \%$ were aged between 10 to 19 years old (adolescent pregnancy) and 3.5\% were over 39 years. Only $2 \%$ and $13 \%$ of the women reported suffering from Diabetes and Hypertension respectively.

In the potential catchment areas, prenatal coverage was almost universal, evidencing the success of this policy in Minas Gerais. Only 15 (1.06\%) women did not have access to antenatal care (results not shown here). FHT supplied care for $68.47 \%$ of the total women who received prenatal care and among those without private health insurance, this percentage increased to $79.51 \%$ (Table 2). These findings revealed that the FHS is the major provider of prenatal care in Minas Gerais. Additionally, FHS coverage is higher among the lower socioeconomic classes. For example, for women without private health insurance and belonging to the D-E classes about $90 \%$ have had prenatal care through FHS while among those belonging to the A and B $68 \%$ indicated that they have had prenatal care through FHS.
Table 1 Distribution of women by socioeconomic characteristics and health status, Minas Gerais, 2012

\begin{tabular}{|c|c|c|}
\hline & Number & Percent \\
\hline \multicolumn{3}{|l|}{ Educational level } \\
\hline Less than completed middle school & 251 & 17.66 \\
\hline $\begin{array}{l}\text { Completed middle school and } \\
\text { incomplete high school }\end{array}$ & 546 & 38.46 \\
\hline Completed high school & 535 & 37.65 \\
\hline Over high school & 88 & 6.23 \\
\hline \multicolumn{3}{|l|}{ Region of residence } \\
\hline Central & 573 & 40.32 \\
\hline North & 224 & 15.78 \\
\hline South & 189 & 13.28 \\
\hline Triângulo Mineiro & 114 & 8.05 \\
\hline Zona da Mata & 191 & 13.43 \\
\hline East & 130 & 9.13 \\
\hline \multicolumn{3}{|l|}{ Economic class } \\
\hline$A-B$ & 325 & 22.90 \\
\hline C & 753 & 53.02 \\
\hline D-E & 342 & 24.08 \\
\hline \multicolumn{3}{|l|}{ Age Group } \\
\hline 10 to 19 & 164 & 11.54 \\
\hline 20 to 24 & 403 & 28.38 \\
\hline 25 to 29 & 386 & 27.21 \\
\hline 30 to 39 & 417 & 29.35 \\
\hline over 40 years & 50 & 3.51 \\
\hline \multicolumn{3}{|l|}{ Health insurance } \\
\hline No coverage & 1059 & 74.60 \\
\hline Coverage & 361 & 25.40 \\
\hline Total & 1,420 & 100.00 \\
\hline \multicolumn{3}{|l|}{ Diabetes } \\
\hline No & 1237 & 97.96 \\
\hline Yes & 26 & 2.04 \\
\hline Total & 1,263 & 100.00 \\
\hline \multicolumn{3}{|l|}{ Hypertension } \\
\hline No & 1099 & 86.87 \\
\hline Yes & 166 & 13.13 \\
\hline Total & 1,265 & 100.00 \\
\hline
\end{tabular}

Note 1: Central $=$ Center + South Center; North $=$ Jequitinhonha + Northwest + North of Minas + Northeast; South $=$ South + West; Triâgulo $=$ North Triângulo + South Triângulo; Zona da Mata = East of South + Southeast; East = East. Note 2: 11.52\% of sample has been omitted to diabetes and $11.33 \%$ to hypertension

Table 3 displays the results for the multivariate logistic model that estimated the likelihood of having received prenatal care by the FHS. The results showed that the chance of having received prenatal care by FHS is five times higher among the lower socioeconomic groups (D-E classes) than A-B classes. The results observed for 
Table 2 Percentage distribution of women who received prenatal care, total and without private health insurance according to economic class (\%), Minas Gerais, 2012

\begin{tabular}{|c|c|c|c|c|c|c|}
\hline \multirow[t]{2}{*}{ Economic Class } & \multicolumn{3}{|c|}{ Total $(N=1405)$} & \multicolumn{3}{|c|}{ Without private health insurance $(N=1069)$} \\
\hline & FHS & Other Public Providers & Private Providers & FHS & Other Public Providers & Private Providers \\
\hline$A-B$ & 45.97 & 3.73 & 50.31 & 68.22 & 4.75 & 27.03 \\
\hline C & 69.11 & 8.25 & 22.64 & 77.29 & 8.09 & 14.62 \\
\hline$D-E$ & 88.72 & 7.09 & 4.18 & 89.86 & 7.14 & 3.00 \\
\hline Total & 68.47 & 6.92 & 24.61 & 79.51 & 7.24 & 13.25 \\
\hline
\end{tabular}

the other socioeconomic indicators such as private health insurance and level of schooling reinforce this pattern of the utilization of antenatal care services: women without private health insurance and with lower educational level are more prone to receive care by FHT. Significant regional differences were observed for women living in the North and Triangulo Mineiro regions, where the odds of receiving prenatal care from FHS were higher than in the Central region.

In Minas Gerais at least $90 \%$ of women received more than 6 antenatal care visits independent of the type of provider and individual characteristics (Table 4). Regarding quality of antenatal care, this survey investigated late prenatal care, tetanus immunization and antenatal tests.

Table 3 Logistic regression for receiving prenatal care provided by the FHS, Minas Gerais, 2012

\begin{tabular}{|c|c|c|}
\hline Variable & Odds ratio & $P$-values \\
\hline Age & $0.97^{* * *}$ & 0.010 \\
\hline Private health insurance & $0.22^{* * *}$ & $<0.001$ \\
\hline Class $C$ (ref. Class $A$ and $B$ ) & $1.81^{* * *}$ & 0.001 \\
\hline Class D-E & $5.09^{* * *}$ & $<0.001$ \\
\hline North Region (ref. Central) & $1.66^{* *}$ & 0.035 \\
\hline South Region & $0.99^{N S}$ & 0.969 \\
\hline Triangulo Mineiro Region & $4.06^{* * *}$ & $<0.001$ \\
\hline Zona da Mata Region & $1.04^{N S}$ & 0.859 \\
\hline East Region & $0.77^{N S}$ & 0.322 \\
\hline Diabetes & $0.33^{* *}$ & 0.020 \\
\hline Hypertension & $0.87^{N S}$ & 0.490 \\
\hline Belo Horizonte (Capital of the State) & $2.02^{* * *}$ & 0.003 \\
\hline $\begin{array}{l}\text { Completed middle school and incomplete high } \\
\text { school (ref. Less than completed middle school) }\end{array}$ & $0.75^{\mathrm{NS}}$ & 0.222 \\
\hline Completed high school & $0.51^{* * *}$ & 0.003 \\
\hline Over high school & $0.66^{\mathrm{NS}}$ & 0.239 \\
\hline Constant & $5.11^{* * *}$ & 0.001 \\
\hline Number of observations & 1,250 & \\
\hline Adjusted $\mathrm{R}^{2}$ & 0.20 & \\
\hline Log of Likelihood & -638.32 & \\
\hline
\end{tabular}

Note: Statistically significant at $1 \%$ margin of error (Sig. level $=99 \%$ );

${ }^{* *}$ Statistically significant at $5 \%$ margin of error (Sig. level $=95 \%$ ). NS not significant. ${ }^{* * *}$ Statistically significant at $1 \%$ margin of error (Sig. level $=99 \%$ )
Table 4 indicates that $10.28 \%$ of women received late prenatal care and only $3.49 \%$ was not immunized. The high prevalence of late prenatal care seems to be associated with adolescent pregnancy (18.53\%) and socioeconomic status (16.25\% among D-E classes).

The results for antenatal tests showed that the coverage was almost $100 \%$ for blood test, urine and STD (Additional file 1: Table S1). The main difference was found only for the toxoplasmosis test, which had a lower coverage, less than 90\%. Besides, it was noticed that about $50 \%$ of each antenatal test were performed by the FHS (Additional file 1: Table S1).

Table 5 shows the chance of having undertaken each prenatal test by FHS. The results show that this probability is inversely associated to socioeconomic status: women belonging to D-E class had at least 5 times more chance to undertake any antenatal test by the FHS compared to those belonging to the A-B classes.

One of the main important outcomes for adequate antenatal care is birthweight. In this survey, around $12 \%$ of the mothers had a child with low birthweight, while in Brazil, this percentage was $8 \%$ in 2010 and among OECD countries, $6.6 \%[43,44]$. Table 6 shows the results for the logistic model estimated for the probability of having a low birthweight infant controlling for mother's and prenatal care characteristics. The most important explanatory factors are mother's age, multiple births and having received antenatal care by FHS. Mothers aged over 40 years old were three times more likely to have a low birthweight infant while multiple births increased the chance by 7 times (Table 6). On the other hand, women whose antenatal care was followed by FHS had a lower chance (40\%) of low birthweight compared to those who received prenatal care by other type of providers (Table 6). Regarding socioeconomic condition, mother's economic class and educational level were not important to explain the prevalence of low birthweight.

\section{Discussion}

Equity can be understood as the absence of systematic and potentially avoidable differences in healthcare access among population groups [45]. Despite its importance, basedpopulation studies dedicated to analyze characteristics of inequalities are scarce [46]. Considering this gap, the 
Table 4 Prevalence of women who received less than 6 ANC visits (total and by FHS), late prenatal care and were not immunized according to socioeconomic characteristics (\%), Minas Gerais, 2012

\begin{tabular}{|c|c|c|c|c|}
\hline & \multicolumn{2}{|c|}{ Less than 6 ANC visits } & \multirow{2}{*}{$\begin{array}{l}\text { Not immunized } \\
(N=1,378)\end{array}$} & \multirow{2}{*}{$\begin{array}{l}\text { Late PNC } \\
(N=1,389)\end{array}$} \\
\hline & $(N=1,392)$ & $(N=980)$ & & \\
\hline & Total & FHS & Total & Total \\
\hline \multicolumn{5}{|l|}{ Region of residence } \\
\hline Central & 8.91 & 8.76 & 3.56 & 11.33 \\
\hline North & 8.98 & 10.54 & 3.99 & 10.67 \\
\hline South & 8.75 & 10.45 & 5.44 & 9.93 \\
\hline Triângulo & 5.67 & 5.95 & 2.60 & 6.49 \\
\hline Zona da Mata & 4.97 & 2.72 & 3.45 & 10.02 \\
\hline East & 5.68 & 5.72 & 4.91 & 9.31 \\
\hline \multicolumn{5}{|l|}{ Economic Class } \\
\hline$A-B$ & 8.24 & 10.01 & 3.48 & 5.53 \\
\hline$C$ & 6.90 & 6.93 & 3.60 & 9.71 \\
\hline D-E & 9.43 & 8.96 & 5.07 & 16.25 \\
\hline \multicolumn{5}{|l|}{ Age Group at pregnancy } \\
\hline 10 to 19 & 16.06 & 15.03 & 2.99 & 18.53 \\
\hline 20 to 24 & 9.72 & 8.69 & 5.10 & 12.19 \\
\hline 25 to 29 & 4.70 & 4.28 & 2.91 & 9.07 \\
\hline 30 to 39 & 6.20 & 7.52 & 4.40 & 7.26 \\
\hline Over 40 years & 2.56 & 2.58 & 1.41 & 1.61 \\
\hline \multicolumn{5}{|l|}{ Education level } \\
\hline Less than completed middle school & 8.44 & 8.12 & 3.39 & 12.27 \\
\hline $\begin{array}{l}\text { Completed middle school and incomplete } \\
\text { high school }\end{array}$ & 11.65 & 9.76 & 5.83 & 14.88 \\
\hline Completed high school & 4.22 & 5.63 & 2.27 & 5.69 \\
\hline Over high school & 4.30 & 8.82 & 3.43 & 4.66 \\
\hline \multicolumn{5}{|l|}{ Private Health Insurance } \\
\hline No & 8.06 & 8.23 & 4.07 & 11.99 \\
\hline Yes & 7.10 & 6.86 & 3.45 & 5.38 \\
\hline \multicolumn{5}{|l|}{ FHS prenatal care } \\
\hline No & - & - & 4.58 & 8.51 \\
\hline Yes & - & - & 2.99 & 11.10 \\
\hline Total & 7.81 & 8.04 & 3.49 & 10.28 \\
\hline
\end{tabular}

present paper investigated inequalities in antenatal care coverage and adequacy in a context of a community based program organized in geographical areas. In Brazil, FHS is the most important national health policy to provide $\mathrm{PHC}$ in the public health sector. The main findings of this paper showed that the coverage of prenatal care is almost universal in catchment urban areas of FHT in Minas Gerais state including both antenatal visits and diagnostic procedures. Due to this high level of coverage, socioeconomic inequalities were not observed. These results are in accordance to the evidence found for low and middle income countries. For instance, Neal et al. [47] compared antenatal care among 35 countries with different levels of coverage and showed that societies with low coverage are more prone to exhibit inequalities.

The universal coverage observed in Minas Gerais is largely explained by the FHS that was responsible for supplying care for around $70 \%$ of the women investigated. This percentage is even higher for those without private health insurance and belonging to lower socioeconomic class, $80 \%$ and $89 \%$ respectively. Women belonging to lower socioeconomic class were at least five times more likely to receive antenatal visits and any of the antenatal tests by the FHS compared to those belonging to the highest classes. These results are strong evidence that FHS promotes equity in antenatal care in 
Table 5 Logistic regression for receiving prenatal tests by the FHS, Minas Gerais, 2012

\begin{tabular}{|c|c|c|c|c|c|c|c|c|}
\hline \multirow[t]{2}{*}{ Variable } & \multicolumn{2}{|l|}{ Blood test } & \multicolumn{2}{|c|}{ Toxoplasmosis } & \multicolumn{2}{|l|}{ Urine test } & \multicolumn{2}{|l|}{ STD test } \\
\hline & Odds Ratio & $P$-values & Odds Ratio & $P$-values & Odds Ratio & $P$-values & Odds Ratio & $P$-values \\
\hline Age & 0.99 & $0.329^{\mathrm{NS}}$ & 0.99 & $0.481^{\mathrm{NS}}$ & 1.00 & $0.723^{\mathrm{NS}}$ & 0.98 & $0.210^{\mathrm{NS}}$ \\
\hline Private health insurance & 0.18 & $0.000^{* * *}$ & 0.22 & $0.000^{* * *}$ & 0.16 & $0.000^{* * *}$ & 0.18 & $0.000^{* * *}$ \\
\hline Class $C$ (ref. Class A and B) & 1.80 & $0.001^{* * *}$ & 1.68 & $0.006^{* * *}$ & 1.90 & $0.001^{* * *}$ & 2.01 & $0.000^{* * *}$ \\
\hline Class D-E & 6.19 & $0.000^{* * *}$ & 5.96 & $0.000^{* * *}$ & 8.15 & $0.000^{* * *}$ & 6.40 & $0.000^{* * *}$ \\
\hline North Region (ref. Central) & 0.99 & $0.960^{\mathrm{NS}}$ & 0.95 & $0.840^{\mathrm{NS}}$ & 0.98 & $0.933^{\mathrm{NS}}$ & 0.96 & $0.883^{\mathrm{NS}}$ \\
\hline South Region & 0.75 & $0.234^{\mathrm{NS}}$ & 0.64 & $0.060^{*}$ & 0.69 & $0.128^{\mathrm{NS}}$ & 0.69 & $0.126^{\mathrm{NS}}$ \\
\hline Mineiro Triangle Region & 6.75 & $0.000^{* * *}$ & 6.22 & $0.000^{* * *}$ & 6.37 & $0.000^{* * *}$ & 6.42 & $0.000^{* * *}$ \\
\hline Zona da Mata Region & 0.71 & $0.151^{\mathrm{NS}}$ & 0.90 & $0.656^{\mathrm{NS}}$ & 0.75 & $0.236^{\mathrm{NS}}$ & 0.74 & $0.219^{\mathrm{NS}}$ \\
\hline East Region & 0.71 & $0.224^{\mathrm{NS}}$ & 0.54 & $0.027^{* *}$ & 0.66 & $0.138^{\mathrm{NS}}$ & 0.58 & $0.048^{* *}$ \\
\hline Diabetes & 0.77 & $0.624^{\mathrm{NS}}$ & 0.71 & $0.529^{\mathrm{NS}}$ & 0.69 & $0.504^{\mathrm{NS}}$ & 0.80 & $0.688^{\mathrm{NS}}$ \\
\hline Hypertension & 0.84 & $0.432^{\mathrm{NS}}$ & 0.79 & $0.302^{\mathrm{NS}}$ & 0.87 & $0.522^{\mathrm{NS}}$ & 0.75 & $0.198^{\mathrm{NS}}$ \\
\hline Belo Horizonte (Capital of the State) & 1.33 & $0.256^{\mathrm{NS}}$ & 1.31 & $0.330^{\mathrm{NS}}$ & 1.57 & $0.084^{*}$ & 1.68 & $0.044^{* *}$ \\
\hline $\begin{array}{l}\text { Completed middle school and incomplete } \\
\text { high school (ref. Less than completed } \\
\text { middle school) }\end{array}$ & 0.91 & $0.718^{\mathrm{NS}}$ & 0.95 & $0.870 \mathrm{NS}$ & 0.90 & $0.692^{\mathrm{NS}}$ & 0.79 & $0.384^{\mathrm{NS}}$ \\
\hline Completed high school & 0.57 & $0.025^{* *}$ & 0.59 & $0.050^{* *}$ & 0.59 & $0.041^{* *}$ & 0.57 & $0.026^{* *}$ \\
\hline Over high school & 0.40 & $0.013^{* *}$ & 0.41 & $0.021^{* *}$ & 0.50 & $0.060^{*}$ & 0.45 & $0.032^{* *}$ \\
\hline Constant & 5.34 & $0.001^{* * *}$ & 4.72 & $0.004^{* * *}$ & 4.42 & $0.004^{* * *}$ & 6.00 & $0.001^{* * *}$ \\
\hline Number of observations & 1,254 & & 1,175 & & 1,251 & & 1,231 & \\
\hline Adjusted $R^{2}$ & 0.24 & & 0.23 & & 0.26 & & 0.25 & \\
\hline Log ofLikelihood & -568.54 & & -528.80 & & -544.60 & & -552.62 & \\
\hline
\end{tabular}

Note: ***Statistically significant at $1 \%$ margin of error (Sig. level =99\%); ${ }^{*}$ Statistically significant at $5 \%$ margin of error (Sig. level = 95\%); ${ }^{*}$ Statistically significant at $10 \%$ margin of error (Sig. level $=90 \%$ ) NS not significant

Minas Gerais. The role of FHS in the provision of antenatal care was also noticed for other localities in Brazil. Bernardes et al. [33] showed that FHS was effective in reducing prenatal care inadequacy. The authors compared prenatal care utilization in São Luis, Maranhão (Northeast region), before (1997/1998) and after FHS implementation (2010). Also Cesar et al. [48] analyzed 23 prenatal care indicators for women in Rio Grande do Sul and showed that the coverage for women receiving care under FHS was similar to the ones in private facilities. Additionally to coverage, adequacy of prenatal care was also observed since $92 \%$ of pregnant women had more than six visits and only $10 \%$ had late prenatal care. These figures are similar for women who received care by FHS suggesting that all essential components of antenatal care are supplied by the public system.

One important neonatal risk factor usually associated with prenatal care is low birthweight, which is also a predictor of child health status. Low birthweight infants are twenty times more likely to die than normal weight ones [40]. In our survey, even though average birthweight was around $3.130 \mathrm{~kg}$, almost $12 \%$ of the children had low birthweight. Besides antenatal care, mother's conditions such as nutritional status, socioeconomic level, presence of hypertension and/or diabetes, drug and tobacco addiction, and age are important risk factors for low birthweight [49-51]. In Minas Gerais, low birthweight seemed to be associated with the mother's age and multiple pregnancy. Moreover, FHS was effective in reducing low birthweight. Women who had prenatal care through FHS were $40 \%$ less likely to have a child with low birthweight. As the coverage of antenatal care is almost universal, there were no significant differences among socioeconomic conditions highlighting once more the importance of FHS.

The success of FHS in providing adequate antenatal care is mainly explained by its design. First, as FHS is part of the public health system all services are provided without out of pocket payments, reducing the financial barriers to healthcare accessibility. Second, FHS is geographically based which guarantees proximity to the services thereby avoiding transportation barriers and minimizing opportunity costs. Usually the burden of transportation costs is higher for poorest population that lives outside the central areas. Third, CHA promotes active search of target populations including pregnant women. This strategy allows for a reduction in educational barriers since less educated individuals are less likely to 
Table 6 Logistic regression for low birthweight, Minas Gerais, 2012

\begin{tabular}{|c|c|c|}
\hline Variable & Odds ratio & $P$-values \\
\hline Class $C$ (ref. Class $A$ and B) & 1.85 & 0.024 \\
\hline Class D-E & 1.10 & 0.797 \\
\hline North Region (ref. Central) & 1.22 & 0.575 \\
\hline South Region & 1.23 & 0.563 \\
\hline Mineiro Triangle Region & 1.09 & 0.844 \\
\hline Zona da Mata Region & 1.95 & 0.036 \\
\hline East Region & 0.58 & 0.260 \\
\hline Belo Horizonte (Capital of the State) & 4.44 & $<0.001$ \\
\hline 20 to 24 (ref. 10 to 19 years old) & 2.04 & 0.163 \\
\hline 25 to 29 & 1.29 & 0.629 \\
\hline 30 to 39 & 1.92 & $0.203^{\mathrm{NS}}$ \\
\hline Over 40 years old & 3.35 & 0.053 \\
\hline $\begin{array}{l}\text { Completed middle school and incomplete high } \\
\text { school (ref. Less than completed middle school) }\end{array}$ & 0.73 & $0.225^{\mathrm{NS}}$ \\
\hline Completed high school & 0.41 & $0.002^{* * *}$ \\
\hline Over high school & 0.91 & $0.838^{\mathrm{NS}}$ \\
\hline Private health insurance & 1.17 & $0.508^{\mathrm{NS}}$ \\
\hline Mother with diabetes & 0.50 & $0.454^{\mathrm{NS}}$ \\
\hline Mother with hypertension & 0.45 & $0.013^{* *}$ \\
\hline Multiple births & 7.72 & $0.004^{* * *}$ \\
\hline Late prenatal care & 0.58 & $0.150^{\mathrm{NS}}$ \\
\hline FHS prenatal care & 0.61 & $0.030^{* *}$ \\
\hline Constant & 0.08 & $0.000^{* * *}$ \\
\hline Number of observations & 1,229 & \\
\hline Adjusted $R^{2}$ & 0.10 & \\
\hline Log of Likelihood & -405.07 & \\
\hline
\end{tabular}

Note: ***Statistically significant at 1\% margin of error (Sig. level =99\%); **Statistically significant at 5\% margin of error (Sig. level =95\%); *Statistically significant at $10 \%$ margin of error (Sig. level $=90 \%$ ) NS not significant

realize the importance of care and where they should search for care. Fourth FHS is a community based program that helps strengthen the relationship between providers and patients. It is worth to mention that $\mathrm{CHA}$ are recruited to work in the communities they reside in, which assures that they can easily identify the local needs of the population. Lassi et al. [52] showed that community based interventions are effective to provide antenatal care in low income countries.

It has to be acknowledged that our data do not consider maternal, infant and child mortality since we only investigated women who had a child under five years old alive in the household at the moment of the interview. In order to take into account these outcome variables a larger sample size, not feasible to our budget, would be required. This limitation could bias our results since maternal and infant mortality can be prevented by adequate antenatal care. Consequently, our results could have underestimated the importance of FHS in promoting comprehensive equity in antenatal care since the study did not analyze data on the role of FHS in lowering infant mortality, which empirical evidence indicates that FHS is capable of reducing infant mortality rates in Brazil [26].

\section{Conclusions}

This paper contributes to the discussion on equity in prenatal care in two ways. First, it analyzed the role of FHS in providing antenatal care considering households located in catchment areas of FHT using a representative sample of urban areas of the state of Minas Gerais. According to the 2010 Brazilian Population Census, 85\% of the population in Minas Gerais lived in urban areas. This survey design helped the study to analyze the effectiveness of FHS taking into account the population that should be covered by the program. 'The study showed that FHS contributed to the promotion of' maternal and child care and with reduction in socioeconomic inequalities in Minas Gerais. Second, this study analyzed the role of FHS in the context of large socioeconomic disparities since Minas Gerais is marked by huge inequalities among regions and among individuals. With in all, FHS was found to be the most important source of access among the poorest individuals without private health insurance while inequalities in prenatal care were not observed.

Equity is usually a measure of outcome concerning PHC. Guaranteed access to antenatal care services without differences regarding socioeconomic status is an important characteristic of health systems organized according the principle of universality. Besides that, there is a lack of studies producing evidences of equity, especially adopting a population-based design [53]. Considering this scenario the contributions provided by our work highlight the importance of strengthen the public primary health care, once it can contribute do overcome access barriers and increase the provision of preventive services.

\section{Additional file}

Additional file 1. Distribution of pregnant women who underwent prenatal tests (total and by FHS) according to economic class (\%) - Minas Gerais - 2012. (DOCX $17 \mathrm{~kb})$

\section{Abbreviations}

CHA: Community health agents; FHS: Family health strategy; FHT: Family health teams; PHC: Primary health care; STD: Sexually transmitted disease

\section{Acknowledgements}

The authors gratefully acknowledge Eugenio Vilaça Mendes for all his comments during the research project. Mônica Viegas Andrade, Kenya Noronha e Allan Claudius would also thank you CNPQ for the the fellowship of research 
productivity (PQ) granted by the National Council for Scientific and Technological Development (CNPq).

\section{Funding}

This research was funded by the Minas Gerais State Department of Health, Government of Minas Gerais.

\section{Availability of data and materials}

Please contact authors for data requests.

\section{Authors' contributions}

MVA, KVMSN, ACB, MNS, JAC, LRC, TAHR and NCS participated in the design of the study, performed the statistical analysis and drafted the manuscript. MVA and KVMSN wrote the final version of the manuscript. All authors have read and approved the final manuscript.

\section{Competing interests}

The authors declare that they have no competing interests.

\section{Consent for publication}

Not applicable.

\section{Ethics approval and consent to participate}

This study was approved by the institutional review board of the Federal University of Minas Gerais, protocol \# 04200203000-10. Informed consents were obtained from all participants.

\section{Author details}

${ }^{1}$ CEDEPLAR, Federal University of Minas Gerais - UFMG, Av. Antônio Carlos 6627, sala 3006, Belo Horizonte, MG 31270-901, Brazil. ${ }^{2}$ CEPEAD, Federal University of Minas Gerais - UFMG, Av. Antônio Carlos 6627, sala 3040, Belo Horizonte, MG 31270-901, Brazil. ${ }^{3}$ Department of Global Health and Population, Harvard T.H. Chan School of Public Health, Boston, MA, USA.

\section{Received: 26 September 2016 Accepted: 25 December 2016}

Published online: 21 January 2017

\section{References}

1. Calderon IMP, Cecatti JG, Vega CEP. Intervenções benéficas no pré-natal para prevenção da mortalidade materna. Rev Bras Ginecol Obstet. 2006;28:310-5.

2. Darmstadt GL, Bhutta ZA, Cousens S, Adam T, Walker N, de Bernis L. Evidence-based, cost-effective interventions: how many newborn babies can we save? Lancet (London, England). 2005;365(9463):977-88.

3. Adam T, Lim SS, Mehta S, Bhutta ZA, Fogstad H, Mathai M, et al. Cost effectiveness analysis of strategies for maternal and neonatal health in developing countries. BMJ (Clinical research ed). 2005;331(7525):1107.

4. Goldie SJ, Sweet S, Carvalho N, Natchu UC, Hu D. Alternative strategies to reduce maternal mortality in India: a cost-effectiveness analysis. PLoS Med. 2010;7(4):e1000264.

5. Jowett M. Safe Motherhood interventions in low-income countries: an economic justification and evidence of cost effectiveness. Health Policy (Amsterdam, Netherlands). 2000;53(3):201-28.

6. Osungbade K, Oginni S, Olumide A. Content of antenatal care services in secondary health care facilities in Nigeria: implication for quality of maternal health care. Int J Qual Health Care. 2008:20(5):346-51.

7. Carroli G, Rooney C, Villar J. How effective is antenatal care in preventing maternal mortality and serious morbidity? An overview of the evidence. Paediatr Perinat Epidemiol. 2001;15 Suppl 1:1-42.

8. Finlayson $\mathrm{K}$, Downe $\mathrm{S}$. Why do women not use antenatal services in lowand middle-income countries? A meta-synthesis of qualitative studies. PLoS Med. 2013;10(1):e1001373.

9. Simkhada B, Teijlingen ER, Porter M, Simkhada P. Factors affecting the utilization of antenatal care in developing countries: systematic review of the literature. J Adv Nurs. 2008:61(3):244-60.

10. Wehby GL, Murray JC, Castilla EE, Lopez-Camelo JS, Ohsfeldt RL. Prenatal care effectiveness and utilization in Brazil. Health Policy Plan. 2009:24(3):175-88.

11. Coimbra LC, Figueiredo FP, Silva AA, Barbieri MA, Bettiol H, Caldas AJ, et al. Inadequate utilization of prenatal care in two Brazilian birth cohorts. Braz J Med Biol Res. 2007;40(9):1195-202.

12. Silveira DS, Santos IS. Adequacy of prenatal care and birthweight: a systematic review. Cad Saude Publica. 2004;20(5):1160-8.
13. Goldani MZ, Barbieri MA, Silva AA, Bettiol H. Trends in prenatal care use and low birthweight in southeast Brazil. Am J Public Health. 2004;94(8):1366-71.

14. Choulagai B, Onta S, Subedi N, Mehata S, Bhandari GP, Poudyal A, et al. Barriers to using skilled birth attendants' services in mid- and farwestern Nepal: a cross-sectional study. BMC Int Health Hum Rights. 2013;13:49.

15. Okwaraji $Y B$, Webb EL, Edmond KM. Barriers in physical access to maternal health services in rural Ethiopia. BMC Health Serv Res. 2015;15:493.

16. Osorio AM, Tovar LM, Rathmann K. Individual and local level factors and antenatal care use in Colombia: a multilevel analysis. Cad Saude Publica. 2014:30:1079-92.

17. Saad-Haddad G, DeJong J, Terreri N, Restrepo-Mendez MC, Perin J, Vaz L, et al. Patterns and determinants of antenatal care utilization: analysis of national survey data in seven countdown countries. J Glob Health. 2016:6(1):010404.

18. Martinelli KG, Santos Neto ET, Gama SGN, Oliveira AE. Access to prenatal care: inequalities in a region with high maternal mortality in southeastern Brazil. Cienc Saude Coletiva. 2016;21:1647-58.

19. Callaghan-Koru JA, McMahon SA, Chebet JJ, Kilewo C, Frumence G, Gupta S, et al. A qualitative exploration of health workers' and clients' perceptions of barriers to completing four antenatal care visits in Morogoro Region, Tanzania. Health Policy Plann. 2016;31(8):1039-49.

20. Fagbamigbe AF, Idemudia ES. Barriers to antenatal care use in Nigeria: evidences from non-users and implications for maternal health programming. BMC Pregnancy Childbirth. 2015;15(1):1-10.

21. Deo KK, Paudel YR, Khatri RB, Bhaskar RK, Paudel R, Mehata S, et al. Barriers to utilization of antenatal care services in Eastern Nepal. Front Public Health. 2015:3:197.

22. Khanal V, da Cruz JL B, Mishra SR, Karkee R, Lee AH. Under-utilization of antenatal care services in Timor-Leste: results from Demographic and Health Survey 2009-2010. BMC Pregnancy Childbirth. 2015;15(1):1-7

23. Van Minh H, Giang KB, Hoat LN, Chung Le H, Huong TT, Phuong NT, et al. Analysis of selected social determinants of health and their relationships with maternal health service coverage and child mortality in Vietnam. Global Health Action. 2016;9:28836

24. Brasil, Ministério da Saúde, Portaria no 2488 de 21 de outubro de 2011 (2011). Available from: http://bvsms.saude.gov.br/bvs/saudelegis/gm/2011/ prt2488_21_10_2011.html.

25. Brasil, Ministério da Saúde, Politica Nacional de Atenção Básica, (2006). Available from: http://dab.saude.gov.br/docs/legislacao/portaria_648_28_03_ 2006.pdf.

26. Rocha R, Soares RR. Evaluating the impact of community-based health interventions: evidence from Brazil's Family Health Program. Health Econ. 2010;19(Suppl):126-58.

27. Macinko J, Guanais FC, de Fatima M, de Souza M. Evaluation of the impact of the Family Health Program on infant mortality in Brazil, 1990-2002. J Epidemiol Community Health. 2006:60(1):13-9.

28. Aquino R, de Oliveira NF, Barreto ML. Impact of the family health program on infant mortality in Brazilian municipalities. Am J Public Health. 2009;99(1):87-93.

29. Macinko J, Dourado I, Aquino R, Bonolo Pde F, Lima-Costa MF, Medina MG et al. Major expansion of primary care in Brazil linked to decline in unnecessary hospitalization. Health Aff (Millwood). 2010;29(12):2149-60.

30. Dourado I, Oliveira VB, Aquino R, Bonolo P, Lima-Costa MF, Medina MG, et al. Trends in primary health care-sensitive conditions in Brazil: the role of the Family Health Program (Project ICSAP-Brazil). Med Care. 2011:49(6):577-84

31. Ceccon RF, Meneghel SN, Viecili PR. Hospitalization due to conditions sensitive to primary care and expansion of the Family Health Program in Brazil: an ecological study. Rev Bras Epidemiol. 2014;17(4):968-77.

32. Anversa ETR, Bastos GAN, Nunes LN, Dal Pizzol TS. Qualidade do processo da assistência pré-natal: unidades básicas de saúde e unidades de Estratégia Saúde da Família em município no Sul do Brasil. Cad Saude Publica. 2012:28:789-800.

33. Bernardes AC, Silva R, Coimbra L, Alves MTSSB, Queiroz RCS, Batista RF. Inadequate prenatal care utilization and associated factors in Sao Luis, Brazil. BMC Pregnancy Childbirth. 2014;14:266

34. World Bank Gini Index [Internet]. Available from: http://data.worldbank.org/ indicator/SI.POV.GINI. Accessed 4 Jan 2017.

35. Atlas do Desenvolvimento Humano no Brasil [Internet]. Programa das Nações Unidas para o Desenvolvimento (PNUD), Fundação João Pinheiro, 
Instituto de Pesquisa Econômica Aplicada (IPEA). Available from: www. atlasbrasil.org.br/2013/ . Acessed on 4th of January, 2017.

36. Malachias I, Amorim ALG, Lélis LB, Pinto MAS, Siqueira M. Plano Diretor de Regionalização de Saúde de Minas Gerais. Belo Horizonte: Secretaria de Estado de Saúde de Minas Gerais; 2013.

37. IBGE. Cadastro Nacional de Endereços para fins estatísticos, 2010. http:// www.censo2010.ibge.gov.br/cnefe/. Accessed 4 Jan 2017.

38. Serruya SJ, Lago TDG, Cecatti JG. O panorama da atenção pré-natal no Brasil e o Programa de Humanização do Pré-natal e Nascimento. Rev Bras Saúde Matern Infant. 2004;4(3):269-79.

39. Silva JLP, Cecatti JG, Serruya SJ. A qualidade do pré-natal no Brasil. Rev Bras Ginecol Obstet. 2005;27(3):103-5.

40. United Nations Children's Fund and World Health Organization. Low birthweight: country, regional and global estimates. New York: UNICEF; 2004.

41. Associação Brasileira de Empresas de Pesquisa. Critério de Classificação Econômica Brasil, 2013. http://www.abep.org/criterio-brasil . Accessed 4 Jan 2017.

42. Pesquisa Nacional de Saúde [Internet]. Instituto Brasileiro de Geografia e Estatistica. 2013 [cited 02092016]. Available from: http://www.ibge.gov.br/ home/estatistica/populacao/pns/2013. Accessed 4 Jan 2017.

43. United Nations Children's Fund (UNICEF). The state of the world's children 2012: Children in an Urban World. New York: UNICEF; 2012.

44. OECD. Health at a Glance 2015: OECD Indicators, Paris, 2015. http://dx.doi. org/ 10.1787/health glance-2015-en. Accessed 4 Jan 2017.

45. Kringos DS, Boerma WG, Hutchinson A, van der Zee J, Groenewegen PP. The breadth of primary care: a systematic literature review of its core dimensions. BMC Health Serv Res. 2010;10(1):1-13.

46. Kringos DS, Boerma WG, Bourgueil Y, Cartier T, Hasvold T, Hutchinson A, et al. The european primary care monitor: structure, process and outcome indicators. BMC Fam Pract. 2010;11(1):1-8.

47. Neal S, Channon AA, Carter S, Falkingham J. Universal health care and equity: evidence of maternal health based on an analysis of demographic and household survey data. Int J Equity Health. 2015;14(1):1-12.

48. Cesar JA, Sutil AT, Santos GB, Cunha CF, Mendoza-Sassi RA. Prenatal care in public and private health services: a population-based survey in Rio Grande, Rio Grande do Sul State, Brazil. Cad Saude Publica. 2012;28(11):2106-14.

49. Gama SGN, Szwarcwald CL, Leal MC, Theme Filha MM. Gravidez na adolescência como fator de risco para baixo peso ao nascer no Município do Rio de Janeiro, 1996 a 1998. Rev Saude Publica. 2001;35:74-80.

50. Viana Kde J, Taddei JA, Cocetti M, Warkentin S. Peso ao nascer de crianças brasileiras menores de dois anos. Cad Saude Publica. 2013;29:349-56.

51. Silvestrin S, Silva CH, Hirakata VN, Goldani AAS, Silveira PP, Goldani MZ. Grau de escolaridade materna e baixo peso ao nascer: uma meta-análise. J Pediatr. 2013:89:339-45.

52. Lassi ZS, Haider BA, Bhutta ZA. Community-based intervention packages for reducing maternal and neonatal morbidity and mortality and improving neonatal outcomes. Cochrane Database Syst Rev. 2010;11:Cd007754.

53. Schäfer WL, Boerma WG, Kringos DS, De Maeseneer J, Greß S, Heinemann S, et al. QUALICOPC, a multi-country study evaluating quality, costs and equity in primary care. BMC Fam Pract. 2011;12(1):1-9.

\section{Submit your next manuscript to BioMed Centra and we will help you at every step:}

- We accept pre-submission inquiries

- Our selector tool helps you to find the most relevant journal

- We provide round the clock customer support

- Convenient online submission

- Thorough peer review

- Inclusion in PubMed and all major indexing services

- Maximum visibility for your research

Submit your manuscript at www.biomedcentral.com/submit

Biomed Central 